\title{
Movements of Kemp's ridley sea turtles nesting on the upper Texas coast: implications for management
}

\author{
Erin E. Seney ${ }^{1,2, *}$, André M. Landry Jr. ${ }^{1}$ \\ ${ }^{1}$ Sea Turtle \& Fisheries Ecology Research Laboratory, Department of Marine Biology, Texas A\&M University at Galveston, \\ 5007 Avenue U, Galveston, Texas 77551, USA \\ ${ }^{2}$ NOAA Fisheries Sea Turtle Facility, NOAA Fisheries Service, US Department of Commerce, 4700 Avenue U, \\ Galveston, Texas 77551, USA
}

\begin{abstract}
Increased nesting by the critically endangered Kemp's ridley sea turtle Lepidochelys kempii at Rancho Nuevo, Mexico has been complemented by commencement and growth of nesting in Texas, USA. Six female Kemp's ridleys were fitted with satellite transmitters after nesting on the upper Texas coast during 2005 and 2006 and subsequently tracked for 20 to 153 d. Two were confirmed nesting a second time on Galveston Island, whereas satellite tracks of these and 2 other females suggested that each nested a total of 3 times on the upper Texas coast within a season. Five of the females showed fidelity to nearshore waters off Galveston Island during their respective nesting seasons, and all 4 ridleys tracked after the nesting season established foraging areas on the continental shelf of Louisiana. One female stranded dead on Galveston Island $20 \mathrm{~d}$ after transmitter deployment. Fidelity of these nesters to the upper Texas coast, along with apparent increases in nesting activity in the region, warrant establishment of sea turtle management schemes comparable to those utilized in south Texas. Potential threats posed by urbanization, tourism, and in-water activities along the upper Texas coast should be addressed by federal, state, and local authorities, whereas increased nesting may also present opportunities for educational outreach and responsible ecotourism.
\end{abstract}

KEY WORDS: Kemp's ridley $\cdot$ Nesting $\cdot$ Satellite telemetry $\cdot$ Tracking $\cdot$ Management $\cdot$ United States Texas Resale or republication not permitted without written consent of the publisher

\section{INTRODUCTION}

The Kemp's ridley sea turtle Lepidochelys kempii is listed as critically endangered by the World Conservation Union and as endangered under the US Endangered Species Act (IUCN 2006, 50 US Code of Federal Regulations [CFR] 17.11). No nesting sites were known for the species until 1961, when Henry Hildebrand discovered a 1947 film depicting a daytime nesting aggregation (arribada) of an estimated 10000 to 40000 females at Rancho Nuevo, Tamaulipas, Mexico (Carr 1963, Hildebrand 1963). By 1965, the largest arribadas at
Rancho Nuevo numbered less than 5000 ridleys (Pritchard 1997), and conservation efforts were initiated by the Mexican National Fisheries Institute (INP) in 1966 (Márquez et al. 2005). The US Fish and Wildlife Service (USFWS) and the Mexican INP began a bi-national research and protection program for Kemp's ridleys at Rancho Nuevo in 1978 (Márquez et al. 2005, Heppell et al. 2007). Exponential nesting increases of 12 to $19 \% \mathrm{yr}^{-1}$ have been observed at Rancho Nuevo since 1985, likely due to egg protection and integration of turtle excluder devices (TEDs) into the US and Mexican shrimp fisheries (Lewison et al. 2003, Heppell et al. 2007). 
Bi-national conservation initiatives at Rancho Nuevo were supplemented by efforts to establish a Kemp's ridley nesting colony at Padre Island National Seashore (PINS) in Texas, USA (Fig. 1) and development of an experimental headstart program at the US National Marine Fisheries Service (NMFS, now the National Oceanic and Atmospheric Administration [NOAA] Fisheries Service) Galveston Laboratory (Klima \& McVey 1982, Fontaine \& Shaver 2005). From 1978 to 2000, 27137 Kemp's ridley hatchlings were transferred to the NMFS Galveston Laboratory from PINS (PINS-imprinted) or directly from Rancho Nuevo (Mexico-imprinted) for captive-rearing (Fontaine \& Shaver 2005, Shaver 2005). The majority of these hatchlings were raised in captivity (i.e. 'headstarted') for 9 to 10 mo, with 23987 conspecifics subsequently tagged and released into the Gulf of Mexico primarily off PINS and Galveston from 1979 to 2003 (Shaver 2005, Shaver \& Wibbels 2007, B. Higgins pers. comm.).

Historical accounts compiled by Hildebrand (1963), Shaver \& Caillouet (1998), and Burchfield (2005) indicate that limited Kemp's ridley nesting was documented along North Padre Island, Texas as early as 1948. This activity grew from 1 to 2 nests annually prior to 1995 (Shaver \& Caillouet 1998) to a record of 102 documented along the Texas coast in 2006 (D. Shaver pers. comm.). Although most ridley nesting in Texas occurs at PINS, 26 nests documented along the upper Texas coast in Brazoria and Galveston Counties from 2002 to 2006 (Shaver et al. 2005a, Shaver \& Wibbels

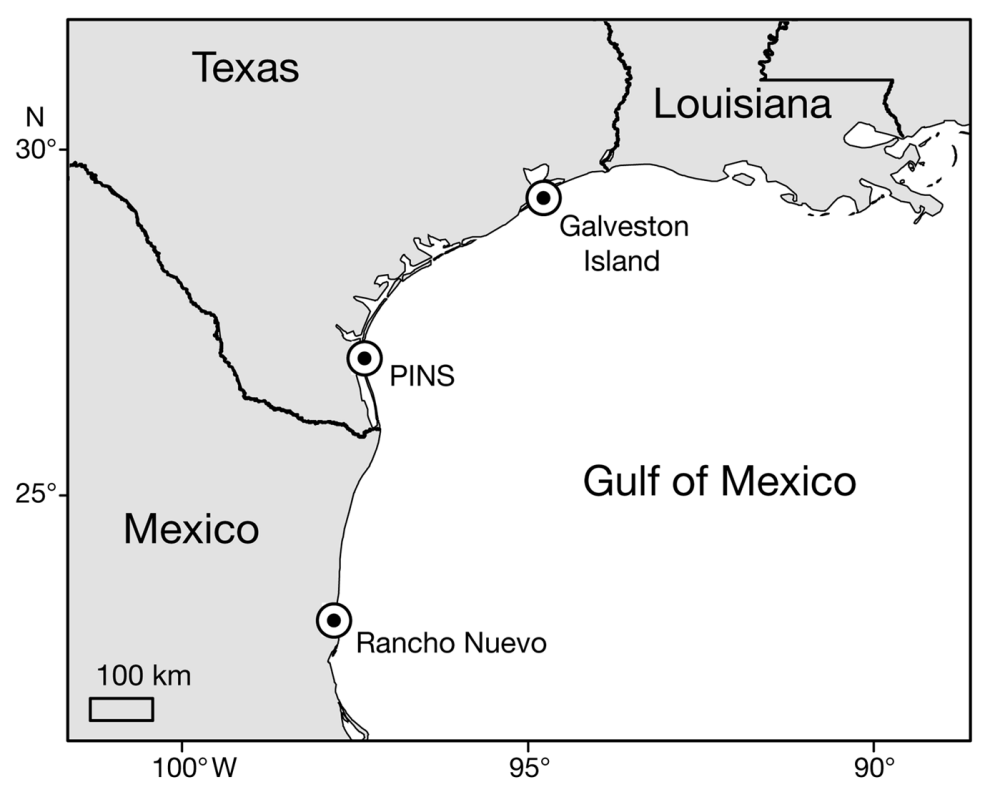

Fig 1. Western Gulf of Mexico showing the locations of Rancho Nuevo, Tampaulipas, Mexico, Padre Island National Seashore (PINS), and Galveston Island, Texas, USA
2007, NOAA Fisheries Sea Turtle Facility [NOAA STF] unpubl. data courtesy of S. Kethan) suggest a reestablishment or northern expansion of the species' nesting range. Nine females that nested on the upper Texas coast from 2002 to 2006 were Mexico-imprinted headstarts from the 1989, 1991, and 1992 year-classes, whereas 3 others were wild (non-headstart) females that lacked both tags and tag scars (Shaver et al. 2005a, Shaver \& Wibbels 2007, NOAA STF unpubl. data courtesy of S. Kethan). These data suggest 'natural' Kemp's ridley nesting on the upper Texas coast, in addition to that by Mexico-imprinted headstarts.

The written history of Galveston Island is largely devoid of specific references to sea turtles on land (cf. sea turtles landed, but not necessarily caught in the area); however, there are 2 specific accounts that, when combined with current knowledge of Kemp's ridley nesting behavior, suggest that recent nesting on the upper Texas coast represents a reestablishment of the species' historical nesting range. Evidence that the upper Texas coast was a historical nesting site is inherent in Burchfield's (2005) suggestion that an account describing 'clusters of mammoth turtles' on a Galveston Island beach during April or May 1851 (Vielé 1858) refers to nesting Kemp's ridleys. Likewise, The Galveston News reported that approximately a dozen sea turtles were encountered on the beach at 41 st Street on Galveston Island on 14 May 1880. Although the newspaper mentions that 'those [sea turtles] usually found in the bay are called loggerheads' (Anonymous 1880), it should be noted that the Kemp's ridley was not formally described as a species until 1880, and as late as the 1970s, ridleys were often sold and reported as loggerhead Caretta caretta meat (Rebel 1974). Even today, the 2 species are often confused by the public, and Kemp's ridleys are also occasionally misidentified as green turtles Chelonia mydas due to their 'greenish' coloration (E. E. Seney pers. obs.). The timing of the 1851 and 1880 accounts suggests Kemp's ridley nesting activity, given that the species often nests during daylight hours, and in April and May, whereas both loggerhead and green turtles typically nest in Texas later in the year and at night (Burchfield 2005, D. Shaver pers. comm.).

The current criteria for downlisting the Kemp's ridley from 'endangered' to 'threatened' under the US Endangered Species Act include attaining 'a population of at least 10000 females nesting in a season' (USFWS \& NMFS 1992). The aforementioned nesting trends, in conjunction with recent reductions in shrimping effort 
in the Gulf of Mexico (LGL Ecological Research Associates 2007) and declines in Texas ridley strandings (Lewison et al. 2003), are indications that this species' recovery is underway. Reaching the goal of 10000 females (USFWS \& NMFS 1992) will require continued management and enforcement efforts, assessing and reducing fishery impacts, evaluation of nearshore time/area fishery closures, and increased efforts to understand the species' ecology and survival (Lewison et al. 2003, Heppell et al. 2007). Additionally, Caillouet $(2005,2006)$ recommends that ongoing revisions to the Kemp's Ridley Recovery Plan (USFWS \& NMFS 1992) reevaluate the 10000-nest benchmark, designate 'Texas beaches as known nesting habitats,' and provide increased protection for all ridley life stages on Texas beaches and in state waters.

Extensive urbanization, development, and tourism along the upper Texas coast, particularly in Galveston County, present additional obstacles that nesting ridleys do not typically encounter at PINS and other protected beaches. Upper Texas coast nesting has occurred near densely populated areas and on beaches subject to vehicular traffic, raking, coastal armoring, and artificial nourishment. Anticipated growth in ridley nesting activity and concurrent use of beaches by humans will likely translate into ecotourism opportunities (Campbell 2003), as well as a vast array of resource management concerns. Characterizing nesting activity and use of Texas coastal waters by ridleys during the nesting season is essential to identifying and resolving conflicts between these activities and those of the beach-going public, in addition to exploring new ecotourism opportunities.

\section{MATERIALS AND METHODS}

Satellite telemetry. Six Kemp's ridleys were selected for tracking after nesting on the upper Texas coast (Galveston and Brazoria Counties) during May 2005 and from April to May 2006. Individuals tracked during 2005 were fitted with Telonics ST-10 $(n=2)$ or ST-20 ( $\mathrm{n}=1$ ) platform terminal transmitters (PTTs), and those tracked during 2006 were fitted with Sirtrack KiwiSat 101 (n=2) or KiwiSat 202 (n=1) PTTs. Prior to transmitter application, each turtle's anterior carapace scutes were sanded and cleaned with acetone. The 2005 PTTs were attached to the carapace with PowerFast two-part marine epoxy. A layer of PowerFast covered by SonicWeld steel-reinforced epoxy putty (Mansfield \& Musick 2004) was used to attach the 2006 units, which were sprayed with a clear antifouling paint (Tempo Marine) prior to attachment. Additionally, two coats of a brush-on antifouling paint (Interlux Micron Extra with 'Biolux') were applied to the non-metal surfaces of the transmitters and cured adhesives in 2006. Each tracked ridley was ultrasounded by J. Flanagan, Doctor of Veterinary Medicine at the Houston Zoo, and released within $24 \mathrm{~h}$ of egg deposition near her initial nesting site.

The Telonics ST-10 and ST-20 and Sirtrack KiwiSat 101 PTTs were set to a duty cycle of $6 \mathrm{~h}$ on: $6 \mathrm{~h}$ off, whereas the KiwiSat 202 unit had a duty cycle of $6 \mathrm{~h}$ on:18 h off. Messages received from satellites were processed by CLS America (formerly Service Argos) to give Doppler-derived locations and classified based on the number of messages used in processing. Location classes (LC) 3, 2, 1, and 0 were derived from at least 4 messages and had estimated accuracies of $<150 \mathrm{~m}$, $<350 \mathrm{~m},<1000 \mathrm{~m}$, and $>1000 \mathrm{~m}$, respectively. The other classes (A, B, Z) did not yield estimates of accuracy. LC A and LC B were calculated from 3 and 2 messages, respectively, whereas LC Z 'indicate[d] that the location process failed' (CLS America 2007, www.clsamerica.com/argos-system/faq.html). Studies using fixed transmitters (Hays et al. 2001) and units attached to captive gray seals Halichoerus grypus (Vincent et al. 2002) have indicated that LC A locations are of similar accuracy to LC 1 and that both LC A and LC B can provide useful information after appropriate filtering.

Data filtering and analysis. Location data were filtered using criteria similar to those utilized in prior studies on adult female olive ridleys Lepidochelys olivacea (Plotkin 1998) and adult male Kemp's ridleys (Shaver et al. 2005b). The SEATURTLE.ORG Satellite Tracking and Analysis Tool (STAT, Coyne \& Godley 2005) was used to exclude locations that fell into any of the following categories: (1) LC Z, (2) locations that required straight-line swimming speeds over $6 \mathrm{~km} \mathrm{~h}^{-1}$, and (3) locations that occurred at elevations over $0.5 \mathrm{~m}$. Obviously erroneous points (e.g. those that 'crisscrossed' land or large areas of water) that remained after the STAT filtering process were removed manually in ArcMap 9.1. Water depth and sea surface temperature at the accepted locations were determined by STAT (Coyne \& Godley 2005) using data produced by NOAA's National Geophysical Data Center and NOAA's Geostationary Operational Environmental Satellites (GOES) sea surface temperature (SST), respectively.

Mean daily locations were generated from the accepted locations for each turtle in order to minimize autocorrelation in spatial analyses (James et al. 2005). The resulting coordinates were included in kernel density estimation (KDE) analyses across all individuals within respective nesting seasons and the 2 nesting seasons combined. Each nesting season was defined by the dates during which nesting was documented on the upper Texas coast. The Home Range Tools for 
ArcGIS extension (Rodgers et al. 2005) and fixed least squares cross-validation smoothing factor $\left(h_{\mathrm{cv}}\right)$ were used for each KDE (Worton 1995, Seaman \& Powell $1996)$, whereas the $50 \%$ probability contour was designated as 'the core area of activity' (Hooge et al. 1999). Each KDE output was clipped in ArcMap 9.1 to exclude land, followed by calculation of the in-water area $\left(\mathrm{km}^{2}\right)$ within each $50 \%$ contour.

The use of duty cycles necessitated examination of tracklines, rather than raw Argos data, to infer nesting events. Each filtered track was visually examined for movement patterns similar to those documented during 2 confirmed nesting events by tracked ridleys. Unconfirmed, but probable, nesting events were inferred at the end of short periods ( 2 to $3 \mathrm{~d}$ ) during which the turtle moved and remained close to shore on the Gulf side of Galveston Island and after which the turtle clearly left the area. In the future, this process could be improved by deploying PTTs without a duty cycle in order to pinpoint nesting events during prolonged haulout times.

Examination of existing management scheme. In addition to examining Kemp's ridley nesting dynamics and post-nesting movements, we sought to apply these results to management of sea turtle nesting along the upper Texas coast. Applicable sea turtle and protected species legislation was identified using resources such as LexisNexis (www.lexisnexis.com), the US Government Printing Office Access website (www.gpoaccess. gov), and the Texas Administrative Code (TAC, www.sos.state.tx.us/tac). Local sea turtle policy, protocols, and practices were compiled from personal knowledge and personal communications with pertinent officials from federal and state agencies.

\section{RESULTS}

The 6 ridleys (Table 1) intercepted while nesting on the upper Texas coast and subsequently tracked averaged $64.0 \mathrm{~cm}$ straight carapace length $(\mathrm{SCL}, \mathrm{SD}=2.1$, $\mathrm{n}=6$ ). All possessed egg follicles prior to transmitter deployment (J. Flanagan unpubl. data), implying that they were likely to nest again during their respective nesting seasons; however, the last turtle tracked in 2006 (RRV233) exhibited much less dense follicles than did the other five nesters (J. Flanagan unpubl. data), suggesting she might not nest again.

The average track duration (Table 1) of $80 \mathrm{~d}(\mathrm{SD}=$ $51, \mathrm{n}=6$ ) included that from a 2005 nester (RRV251) that stranded deadi excluding this track increased average track duration to $92 \mathrm{~d}(\mathrm{SD}=47, \mathrm{n}=5)$. The stranded turtle, which was reported and examined within a few hours of death, exhibited no external abnormalities other than 4 areas of exposed bone on the plastron and moderate barnacle coverage on the PTT. A necropsy of RRV251 revealed signs of both trauma and drowning, including hemorrhaging in both pectoral muscles and fluid and clotted blood in the lungs (J. Flanagan \& E. Seney unpubl. data), whereas a histological examination by the Texas Veterinary Medical Diagnostic Laboratory identified parasitic ova in some tissues (P. Varner unpubl. data). There were no indications that the PTT had any impact on this turtle's health, and none of the Argos data or tracks suggested that any of the other females were dead or debilitated at the time transmissions ceased. Barnacle growth seen on the stranded ridley's PTT and on that of SSD127 at her second documented nesting event suggested that fouling of the saltwater switches may

Table 1. Lepidochelys kempii. Nesting and tracking details for 6 Kemp's ridley sea turtles from the upper Texas coast, $2005-2006$. Turtle type details in parentheses: HS, headstart (including year); W, wild; SCL, straight carapace length (from notch to tip); PTT, platform terminal transmitter manufacturer and type; No. accepted locations, locations remaining after filtering raw Argos data

\begin{tabular}{|c|c|c|c|c|c|c|c|c|}
\hline $\begin{array}{l}\text { Turtle ID } \\
\text { (type) }\end{array}$ & $\begin{array}{l}\mathrm{SCL} \\
(\mathrm{cm})\end{array}$ & $\begin{array}{l}\text { Initial nesting } \\
\text { location }\end{array}$ & PTT & $\begin{array}{c}\text { Date of } \\
\text { deployment }\end{array}$ & $\begin{array}{l}\text { No. of days } \\
\text { tracked }\end{array}$ & $\begin{array}{l}\text { No. accepted } \\
\text { locations }\end{array}$ & $\begin{array}{c}\text { Confirmed } \\
\text { nesting date(s) }\end{array}$ & $\begin{array}{c}\text { Inferred } \\
\text { nesting date(s) }\end{array}$ \\
\hline $\begin{array}{l}\text { SSD127 } \\
\text { (1992 HS) }\end{array}$ & 65.8 & Galveston Is. & Telonics ST-10 & 17 May 2005 & 44 & 27 & $\begin{array}{l}16 \text { May } 2005 \\
20 \text { June } 2005\end{array}$ & 4 June 2005 \\
\hline $\begin{array}{l}\text { RRV251 } \\
\text { (W) }\end{array}$ & 62.5 & Galveston Is. & Telonics ST-10 & 29 May 2005 & $20^{\mathrm{a}}$ & 8 & 29 May 2005 & None \\
\hline $\begin{array}{l}\text { RRV253 } \\
\text { (1992 HS) }\end{array}$ & 63.0 & Galveston Is. & Telonics ST-20 & 31 May 2005 & 50 & 93 & 30 May 2005 & $\begin{array}{l}13 \text { June } 2005 \\
26 \text { June } 2005\end{array}$ \\
\hline $\begin{array}{l}\text { RRV231 } \\
\text { (W) }\end{array}$ & 67.2 & Galveston Is. & Sirtrack KS101 & 28 Apr 2006 & 146 & 170 & 28 April 2006 & $\begin{array}{l}19 \text { May } 2006 \\
14 \text { June } 2006^{b}\end{array}$ \\
\hline $\begin{array}{l}\text { RRV315 } \\
\text { (1989 HS) }\end{array}$ & 61.5 & Galveston Is. & Sirtrack KS101 & 7 May 2006 & 87 & 197 & $\begin{array}{c}6 \text { May } 2006 \\
26 \text { May } 2006\end{array}$ & 10 June 2006 \\
\hline $\begin{array}{l}\text { RRV233 } \\
\text { (W) }\end{array}$ & 63.8 & Surfside & Sirtrack KS202 & 27 May 2006 & 132 & 190 & 27 May 2006 & None \\
\hline
\end{tabular}


have been a cause of transmission loss in 2005. Antifouling paints were incorporated into the attachment protocol in 2006, likely contributing to the increase in average track duration (mean, $\bar{x} \pm 1 \mathrm{SD}=122 \pm 32 \mathrm{~d}$, $\mathrm{n}=3$ ). Additionally, the antenna on SSD127's PTT was bent nearly parallel to the turtle's carapace when she renested, suggesting antenna loss as another possible cause of transmission loss for both years.

\section{Internesting habitat}

SSD127 and RRV315 were confirmed renesting via visual observations 35 and 20 d, respectively, after initial nesting encounters, whereas satellite tracks of these females and 2 other individuals (RRV253, RRV231) indicated they nested again in the Galveston
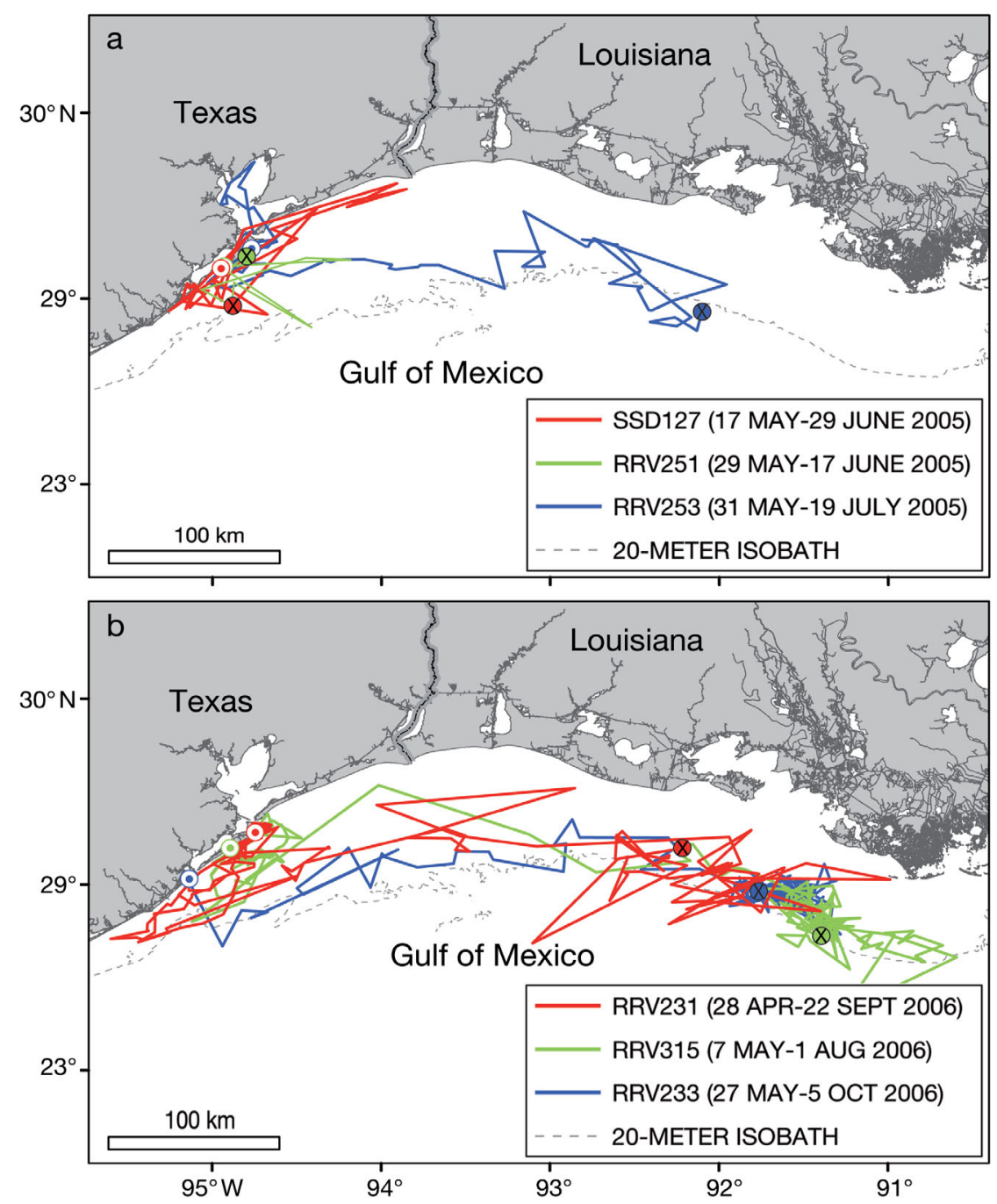

Fig. 2. Lepidochelys kempii. Filtered tracks for 6 Kemp's ridley sea turtles encountered nesting on the upper Texas coast during (a) 2005 and (b) 2006. ๑: start; $\otimes:$ end point of each track area (Fig. 2, Table 1). Based on documented nesting events and satellite tracks, it was estimated that each of these 4 ridleys nested on the upper Texas coast a total of 3 times, at 2 to 3 wk intervals (Table 1). RRV251 stranded dead $20 \mathrm{~d}$ after her first nesting encounter, and no shelled eggs were found during the necropsy, suggesting she may have nested again prior to stranding. The last female tracked (RRV233) exhibited fewer follicles at the time of ultrasound and immediately left the upper Texas coast after PTT deployment, indicating she had completed her nesting cycle. Given that Kemp's ridleys typically lay 2 to 3 nests per year (Turtle Expert Working Group 2000, Rostal 2005), it is likely that RRV233 nested undetected earlier in the 2006 season.

Core areas of activity (50\% kernel contours) for the 2005 nesting season (16 May to 20 June), 2006 nesting season (28 April to 14 June), and both nesting seasons combined centered on Galveston Island (Fig. 3). Approximately $80 \%$ of the accepted locations during the 2 nesting seasons occurred in waters less than $10 \mathrm{~m}$ deep. During these time periods, GOES SST data were available for 221 of the filtered locations, and the 6 ridleys occupied waters at 24.5 to $30.7^{\circ} \mathrm{C} \mathrm{SST}(\bar{x} \pm 1 \mathrm{SD}=27.0 \pm$ $1.7^{\circ} \mathrm{C}$ ) during their respective nesting seasons.

\section{Migration and foraging habitat}

Of the post-nesting ridleys, 4 were tracked beyond the May to June 2005 (RRV253) and April to June 2006 (RRV231， RRV315, RRV233) nesting seasons (Fig. 2). These turtles migrated along the Texas and Louisiana continental shelf, predominantly in waters less than $20 \mathrm{~m}$ deep. All four established foraging sites offshore of the central Louisiana coast (Vermilion, Iberia, St. Mary, and Terrebonne Parishes), and remained in waters 10 to $30 \mathrm{~m}$ deep throughout the duration of their tracks. SST values recorded after the nesting season were 27.7 to $31.6^{\circ} \mathrm{C}(\bar{x} \pm 1 \mathrm{SD}=$ $\left.29.8 \pm 0.8^{\circ} \mathrm{C}, \mathrm{n}=394\right)$; however, departure of these females from the Galveston area did not correlate with any temperature changes. 

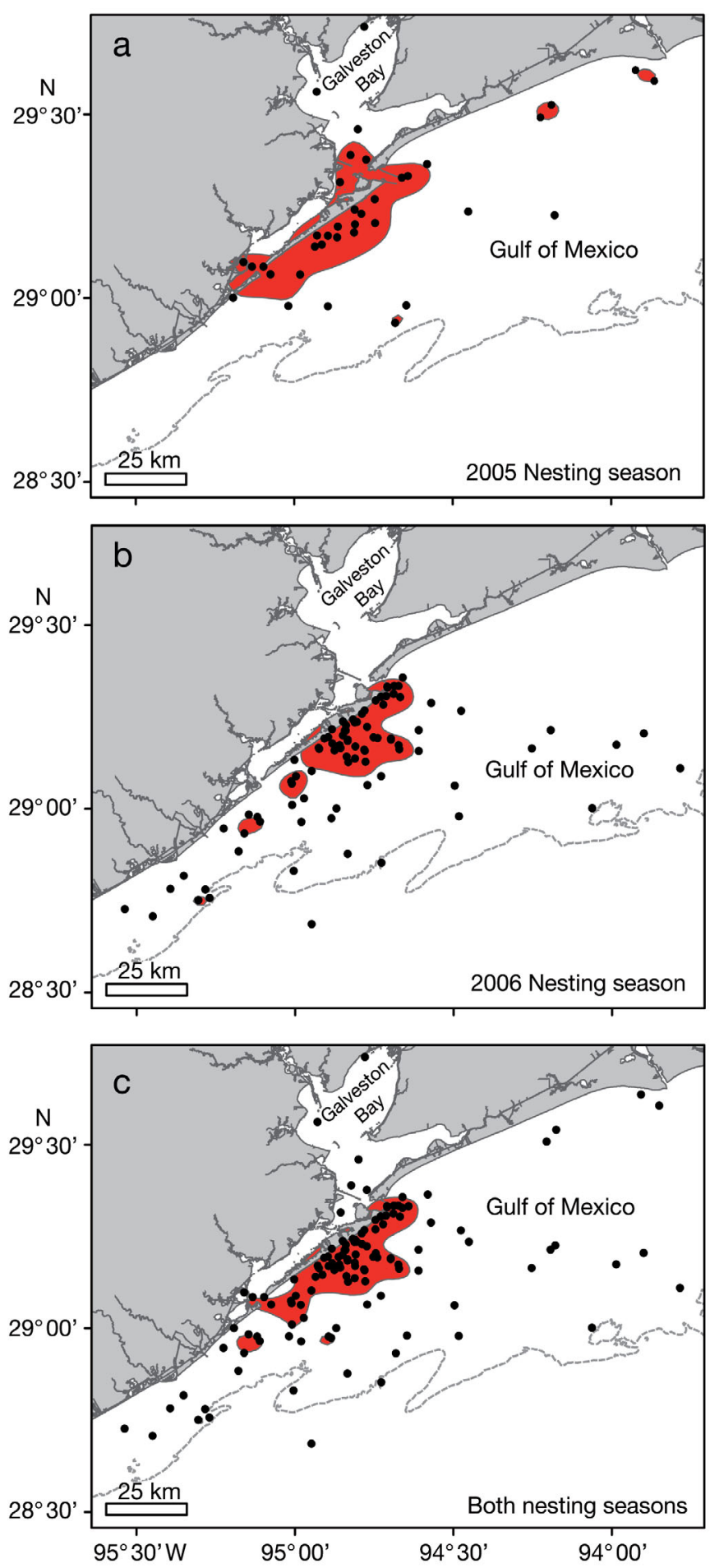

Fig. 3. Lepidochelys kempii. Mean daily locations (•) for each turtle and core areas of activity (50\% kernel contours, red shaded areas) during the (a) $2005\left(\mathrm{n}=37, h_{\mathrm{cv}}=0.193\right)$, (b) 2006 ( $\left.\mathrm{n}=87, h_{\mathrm{cv}}=0.148\right)$, and (c) combined 2005-2006 ( $\mathrm{n}=124$, $\left.h_{\mathrm{cv}}=0.133\right)$ upper Texas coast Kemp's ridley nesting seasons, where $\left(h_{\mathrm{cv}}\right)$ is the fixed least squares cross-validation smoothing factor. The $50 \%$ kernel contours encompass $1017 \mathrm{~km}^{2}$, $622 \mathrm{~km}^{2}$, and $716 \mathrm{~km}^{2}$ of in-water area in (a), (b) and (c), respectively. Dashed lines: $20 \mathrm{~m}$ isobath

\section{Nesting management on the upper Texas coast}

Examination of ridley nesting management on the upper Texas coast required consideration of stakeholders ranging from international to federal, state, and local entities to non-governmental organizations (NGOs), members of the public, and the turtles themselves. The primary stakeholders identified for upper Texas coast ridley nesting are listed in Table 2 and further described in the following.

The USA and Mexico are parties to the Inter-American Convention for the Protection and Conservation of Sea Turtles (IAC Secretariat 2004), which requires they undertake appropriate measures to protect and conserve sea turtle species and their habitats. The Kemp's ridley was originally listed in the USA as an endangered species in 1970 (50 CFR 17.11, as amended 2 December 1970) and is currently protected under the US Endangered Species Act of 1973 (ESA, 7 United States Code [USC] 136, 16 USC 460 et seq.). Sea turtles fall under the jurisdictions of the USFWS (50 CFR 17.11) and NOAA Fisheries Service ( 50 CFR 222.23, 50 CFR 227.4), whereas Section 7 of the ESA requires other federal agencies to consult with USFWS and NOAA regarding any activities that may impact sea turtles. Measures must be taken to reduce bycatch, including sea turtles, in US fisheries under the Magnuson-Stevens Fishery Conservation and Management Act (MSFCMA), as overseen by the NOAA Fisheries Service (16 USC 1801 et seq.), and this requirement is also inherent in the IAC. The NOAA Fisheries Service (50 CFR 222.23, 50 CFR 227.4), USFWS (50 CFR 17.11), and US Coast Guard (50 CFR 622.41) provide federal enforcement of sea turtle regulations, and the USFWS oversees the National Wildlife Refuge System (50 CFR 25.11), which includes 5 refuges along the Texas Gulf coast.

Within Texas, USFWS currently defers to the National Park Service (NPS), specifically PINS (36 CFR 7.75), regarding protocols for collection of sea turtle nesting data, nest relocation, and incubation of eggs (D. Shaver pers. comm.). The length of the Texas coast necessitates dividing sea turtle nesting patrols, nesting response, and stranding response among multiple agencies, including NPS and various national wildlife refuges, state universities, and non-profit organizations. The NOAA STF currently conducts nesting and stranding response, data collection, and nest excavations on the upper Texas coast, per a memorandum of understanding with USFWS (C. Yeargan pers. comm.). Additionally, Texas A\&M University at Galveston (TAMUG) has assisted the NOAA STF with nesting response since 2005 and will take on a larger role in 2008.

The Texas Parks and Wildlife Department (TPWD) has jurisdiction over protected species in Texas, 
Table 2. Primary stakeholders for Kemp's ridley nesting on the upper Texas coast

\begin{tabular}{|c|c|}
\hline Stakeholder & Role/interest \\
\hline \multicolumn{2}{|l|}{ International } \\
\hline $\begin{array}{l}\text { Inter-American Convention for the Protection } \\
\text { and Conservation of Sea Turtles (IAC) }\end{array}$ & Ratified by 12 nations (in force May 2001) ${ }^{a}$ \\
\hline Mexico & Primary nesting ground located in Tamaulipas. ${ }^{\mathrm{b}}$ IAC party ${ }^{\mathrm{a}}$ \\
\hline United States & Secondary nesting grounds along Texas coast. ${ }^{c}$ IAC party ${ }^{\mathrm{a}}$ \\
\hline \multicolumn{2}{|l|}{ Federal } \\
\hline National Park Service & $\begin{array}{l}\text { Oversees National Seashore system. }{ }^{\mathrm{d}} \text { (Includes Padre Island National } \\
\text { Seashore's nesting response and monitoring, research, and manage- } \\
\text { ment of Texas nesting data per agreement with USFWS) }\end{array}$ \\
\hline NOAA Fisheries Service & $\begin{array}{l}\text { Jurisdiction over sea turtles in the water. }{ }^{\mathrm{e}} \text { (Includes upper Texas coast } \\
\text { nesting response by NOAA Fisheries Galveston per agreement with } \\
\text { USFWS) }\end{array}$ \\
\hline US Army Corps of Engineers & Beach renourishment and channel dredging ${ }^{\mathrm{f}}$ \\
\hline US Fish \& Wildlife Service & $\begin{array}{l}\text { Jurisdiction over sea turtles on land. } .^{g} \text { Oversees National Wildlife } \\
\text { Refuge system }{ }^{\mathrm{h}} \text { (Texas Point, McFaddin, San Bernard, Aransas, and } \\
\text { Laguna Atascosa National Wildlife Refuges are located on the Texas } \\
\text { gulf coast). Local USFWS offices defer to PINS for state nesting } \\
\text { program managment and to NOAA Fisheries Galveston for upper } \\
\text { Texas coast nesting response }{ }^{\mathrm{i}}\end{array}$ \\
\hline \multicolumn{2}{|l|}{ State of Texas } \\
\hline Texas General Land Office & Jurisdiction over beach projects and dune related activities in $\mathrm{Texas}^{\mathrm{j}}$ \\
\hline Texas Parks and Wildlife Department & $\begin{array}{l}\text { Jurisdiction over protected species and fisheries in Texas. Oversees } \\
\text { Texas state park system (Sea Rim, Galveston Island, and Mustang } \\
\text { Island State Parks are located on the Texas gulf coast) }\end{array}$ \\
\hline Texas A\&M University System & Sea turtle research and upper Texas coast nesting response \\
\hline University of Texas System & Sea turtle research and middle Texas coast nesting response \\
\hline \multicolumn{2}{|l|}{ County and local } \\
\hline Brazoria County & Local government and law enforcement \\
\hline Chambers County & Local government and law enforcement \\
\hline Galveston County & Local government and law enforcement \\
\hline Jefferson County & Local government and law enforcement \\
\hline City of Galveston (Galveston County) & Local government and law enforcement \\
\hline City of Jamaica Beach (Galveston County) & Local government and law enforcement \\
\hline Village of Surfside (Brazoria County) & Local government and law enforcement \\
\hline \multicolumn{2}{|l|}{ Texas-based non-governmental organizations } \\
\hline Coastal Conservation Association (CCA) - Texas & $\begin{array}{l}\text { Promotes conservation of marine species, particularly recreational } \\
\text { gamefish (www.ccatexas.org) }\end{array}$ \\
\hline Help Endangered Animals-Ridley Turtles (HEART) & Public education and fundraising (www.ridleyturtles.org) \\
\hline Recreational Fishing Alliance - Texas State Chapter & $\begin{array}{l}\text { Promotes conservation of marine species, particularly recreational } \\
\text { gamefish (www.rfatexas.org) }\end{array}$ \\
\hline Texas Open Beach Advocates (TOBA) & $\begin{array}{l}\text { Promotes each access rights, public education and stewardship } \\
\text { (www.texasopenbeaches.org) }\end{array}$ \\
\hline Texas Shrimp Association & Represents interests of Texas shrimpers \\
\hline General public & \\
\hline Global community & Intrinsic and existence value of species. ${ }^{1}$ Educational values ${ }^{\mathrm{m}}$ \\
\hline Texas coast residents & $\begin{array}{l}\text { Intrinsic and existence value of species. }{ }^{1} \text { Educational values. }{ }^{\mathrm{m}} \\
\text { Possible interactions with nesting turtles/nests/hatchlings }{ }^{\mathrm{n}}\end{array}$ \\
\hline Texas coast businesses & $\begin{array}{l}\text { Possible interactions with nesting turtles/nests/hatchlings. }{ }^{n} \text { Possibility } \\
\text { for ecotourism }{ }^{\mathrm{m}}\end{array}$ \\
\hline Texas coast visitors & $\begin{array}{l}\text { Possible interactions with nesting turtles/nests/hatchlings. }{ }^{\mathrm{n}} \text { Educa- } \\
\text { tional values }{ }^{\mathrm{m}}\end{array}$ \\
\hline${ }^{\mathrm{a}} \mathrm{IAC}$ Secretariat (2004) & ez et al. (2005) \\
\hline 'Shaver (2005) & \\
\hline e50 CFR 222.23, 50 CFR 227.4 & 320.1 \\
\hline 950 CFR 17.11 & 25.11 \\
\hline iPer memorandum of understanding & $15,16,25$ \\
\hline${ }^{\mathrm{k}} 31 \mathrm{TAC} 55,57,58,59,65$ & ngton \& Frazer (2003) \\
\hline${ }^{\mathrm{m}}$ Campbell (2003) & \& NMFS (1992) \\
\hline
\end{tabular}


including all federally protected species and others threatened with extinction within the state (31 TAC 65, 5 Texas Parks and Wildlife Code [TPWC] 68). TPWD also maintains the state park system and constituent beaches (31 TAC 59) and oversees commercial and recreational fishing activities in state waters, which extend 9 nautical miles offshore of the Texas coast (31 TAC 57-58, 5 TPWC 46-47,66). In addition to permitting research and recovery activities in Texas, TPWD's primary role with regard to sea turtles is that of in-water enforcement (M. Ray pers. comm.). All shrimpers must comply with state and federal TED regulations and with shrimp fishery closures, which occur annually along the upper Texas coast from 15 May to 15 July and along the lower and middle Texas coast from 1 December to 15 July (TPWD 2006).

The Texas General Land Office (TGLO) is tasked with management of human impacts on the state's beach/dune system, including the conservation of 'flora and fauna and their habitat' and acting in accordance with federal and TPWD protected species regulations (31 TAC 15). State and federally-funded beach and dune projects that impact sea turtles are required by TGLO to have appropriate USFWS consultation, mitigation, and/or monitoring, in addition to applicable US Army Corps of Engineers (USACE) and state permits (B. Rhame pers. comm.). Locally and privately-funded beach projects are also required to obtain appropriate permits, and TGLO recommends (but does not require) that those projects with potential sea turtle impacts contact USFWS for consultation (B. Rhame pers. comm.).

Local citizens, businesses, and visitors are also stakeholders for upper Texas coast nesting issues, and their voices are often heard through local and national NGOs, increasingly in the form of lawsuits. The 1989 decision of the US District Court for the District of Columbia in National Wildlife Federation, et al. v. Robert A. Mosbacher, U.S. Secretary of Commerce required NMFS to reinstate suspended TED regulations and enforcement (1989 US Dist Lexis 9748). Likewise in 1995, the US District Court for Orlando, Florida held that a 'species protected under [the] ESA has standing to sue on its own right to enforce provisions of [the] ESA' in its decision of Loggerhead Turtle et al. v. the County Council of Volusia County, Florida (896 Fed Suppl 1170, p. 1177). Although the vitality of endangered species' legal standing has been questioned, recent lawsuits have successfully forced state and local governments to enforce the ESA (Brader 2005).

Houston, Texas-based HEART (Help Endangered Animals-Ridley Turtles) is the Gulf of Mexico office for the California-based Sea Turtle Restoration Project (STRP), and is an NGO focused primarily on public awareness, including volunteer nesting patrols, fundraising, and activism (HEART, www.savetexasseaturtles.org/). HEART is particularly vocal with regard to issues pertaining to shrimping and Kemp's ridley nesting, and both HEART and STRP were plaintiffs in a 1994 civil suit brought against NMFS (C. Allen pers. comm.) that resulted in an Emergency Response Plan detailing federal policy to ensure compliance of sea turtle regulations (NOAA 1995).

Commercial marine fisheries are also represented by NGOs, including the Texas Shrimp Association, and such organizations have a vested interest in the impact of sea turtle regulations on their industries. Likewise, recreational anglers are represented by a variety of organizations (e.g. Coastal Conservation Association, Texas and the Recreational Fishing Alliance, Texas State Chapter), and a subset of this group may include anglers who, like many Texas beachgoers, currently drive legally on beaches where sea turtle nesting has been documented. Texas Open Beach Advocates (TOBA) is a Galveston Island-based group that promotes free public access to Texas beaches, including driving, under the Texas Open Beaches Act (61 Texas Natural Resources Code 011), as well as stewardship and preservation of beaches (TOBA, www.texasopenbeaches.org/open.htm).

\section{DISCUSSION AND CONCLUSIONS}

Marine turtle satellite telemetry has grown from the experimental tracking of adult female loggerhead sea turtles during 1979 and 1980 (Stoneburner 1982, Timko \& Kolz 1982) to a standard method for examining movements of 6 of the world's 7 species (Godley et al. 2008, this Theme Section). Satellite tracking has been utilized to document extended post-nesting movements, such as those of leatherback turtles Dermochelys coriacea spanning the Atlantic (James et al. 2005) and Pacific Oceans (Benson et al. 2007), as well as more localized internesting movements (e.g. olive ridleys: Plotkin 1998; loggerheads: Stoneburner 1982, Godley et al. 2003; green turtles: Hays et al. 1999, Troëng et al. 2005b; and hawksbill turtles Eretmochelys imbricata: Troëng et al. 2005a, Whiting et al. 2006).

Use of satellite telemetry on adult Kemp's ridleys was preceded by deployment of radio transmitters on 9 post-nesting individuals at Rancho Nuevo in 1980. These females exhibited random movement in the vicinity of the nesting beach for up to $2 \mathrm{~d}$ and subsequently displayed longshore movements of at least $10 \mathrm{~km}$ (Mendonça \& Pritchard 1986). Fourteen postnesting females satellite tracked from Rancho Nuevo in 1987 and 1988 remained in coastal waters less than $50 \mathrm{~m}$ in depth (R. Byles unpubl. data). Individual adult females tracked by Renaud et al. (1996) and Gitschlag 
(1996) exhibited longshore migrations, with the individual observed by the former being tracked from foraging grounds in Louisiana to Rancho Nuevo, where she was documented nesting.

\section{Implications of telemetry results}

Satellite tracks for Kemp's ridleys nesting on the upper Texas coast in 2005 and 2006 provided evidence that this region holds unknown potential as nesting habitat. Although these data and tracks were based on a limited sample of ridleys from the Galveston area, the number of nesters on the upper Texas coast is annually increasing in a fashion similar to that at PINS (Shaver \& Rubio 2008, this Theme Section), where most of the state's nesting activity has occurred historically (Shaver \& Caillouet 1998). Additionally, the number of nests documented on the upper Texas coast from 2002 to 2006 is likely a conservative number, given the lack of standardized nesting patrols and outreach required to educate the beach-going public to report nesting activity. These issues are currently being addressed by TAMUG and HEART, and standardized nesting patrols, volunteer patrols, and increased public outreach occurred during 2007.

Nesting activity and internesting movements summarized above in 'Results' suggest that upper Texas coast beaches provide nesting habitat to both headstarted and 'wild' Kemp's ridleys that spend their internesting intervals in waters adjacent to these beaches from approximately April to June. Satellite telemetry data, along with ultrasound detection of developing follicles, also suggest each of these females nested more than once on upper Texas coast beaches. Although tracks were of limited duration, core activity areas generated from filtered data indicate relatively restricted, nearshore movement among nesters during the inter-nesting period. This restricted movement implies a strong fidelity to the upper Texas coast that is supported by the confirmed renestings by SSD127 and RRV315 on Galveston Island. Similar fidelity has been exhibited by other female ridleys along PINS during the nesting season (Shaver \& Rubio 2008). The postreproductive migrations by 4 upper Texas coast nesters along the Texas and Louisiana continental shelf also mirrored movements of many females tracked from PINS (Shaver \& Rubio 2008) and 4 tracked from Galveston in 2007 (A. Landry \& C. Hughes unpubl. data). Likewise, immature ridleys tracked from seasonal foraging grounds along the northwestern Gulf of Mexico (Renaud \& Williams 2005), the Florida Gulf coast (Schmid \& Witzell 2006), and New York (Morreale $\&$ Standora 2005) utilized nearshore waters for both foraging and migration.
Documentation of nesting activity on the upper Texas coast also provided evidence that Kemp's ridleys nest along the upper Texas coast and establish fidelity to constituent habitats during some or all phases of the nesting season. This nesting activity, like that seen in preliminary trends in south Texas (Shaver \& Caillouet 1998), is likely to increase with this species' ongoing recovery. This increase will result in more mature females utilizing upper Texas coast waters and beaches where they lack the levels of protection currently afforded them along the middle and lower coast, including the extended nearshore shrimp closure and protected beaches along PINS.

The need for mitigation measures, such as regulations affording increased protection to sea turtles along upper Texas beaches and coastal waters, should be examined and considered by state and federal managers in order to reduce threats to the increasing number of nesting Kemp's ridleys in the region and their progeny. Such measures will help to (1) ensure the realization of any latent nesting potential along the upper Texas coast, (2) increase researchers' and regulatory personnel's ability to assess this nesting activity and the importance of constituent beaches to ridley recovery, (3) develop management strategies that incorporate upper Texas coast beaches and adjacent waters, (4) maintain and enhance the integrity of nesting habitat and adjacent waters, and (5) increase the potential for educational outreach and responsible ecotourism on upper Texas coast beaches.

\section{Nesting management on the upper Texas coast}

The likelihood of increased Kemp's ridley nesting and associated human interactions on the upper Texas coast warrants a proactive and coordinated management approach in order to comply with the ESA and Kemp's Ridley Recovery Plan, avoid civil lawsuits, and enhance opportunities for nature-based educational outreach and tourism. Nesting response and documentation on the upper Texas coast should continue within the framework of the statewide program overseen by PINS; however, a highly developed coastal zone and involvement of multiple agencies and municipalities necessitate a more complex management approach than that taken along the protected beaches of south Texas. The USFWS has primary jurisdiction over sea turtle nesting, and as such, the agency has a responsibility to spearhead integrated ridley nesting management efforts on the upper Texas coast or to designate a surrogate agency to do so. The PINS program, along with requirements set forth by the ESA, Kemp's Ridley Recovery Plan, and various federal and state regulations, provide substantial framework for nesting man- 
agement on the upper Texas coast. Guidance applicable to urban areas may be gleaned from international documents such as the Rio Declaration on the Environment and Development (United Nations 1992) and the International Chamber of Commerce (ICC) Business Charter for Sustainable Development (ICC 1991), including use of a precautionary, rather than reactionary, approach.

An examination of sea turtle policies and practices within the state of Florida may provide a further framework for TPWD and TGLO to minimize sea turtle-human interactions on Texas nesting beaches, particularly in urban areas along the upper Texas coast. Florida's Marine Turtle Protection Act (Florida Statute 370.12) outlines general guidelines for the state, and specific issues are further outlined in the Florida Administrative Code (FAC). The state has developed a model lighting ordinance for marine turtle protection to guide local governments in creating their own ordinances (62B FAC 55). Additionally, the Florida Fish and Wildlife Conservation Commission (FWC) provides guidelines for minimizing effects of lighting, beach furniture, mechanical beach cleaning, and coastal armoring on sea turtles (FWC 2002). Florida's Bureau of Beaches and Coastal Systems must ensure that beach construction activities 'will not cause a significant adverse impact to marine turtles,' and that measures are taken to protect turtles and their habitat, which may include limitations on the nature and timing of permitted activities (62B FAC 33).

Effective management of sea turtle nesting and human interactions along developed beaches of the upper Texas coast requires cooperation by local governments with state and federal agencies involved in sea turtle nesting response and management. South Padre Island, Texas, which is comprised primarily of developed beaches, may present an appropriate sea turtle nesting 'model' for developed areas of the upper Texas coast in Galveston and Brazoria Counties. In contrast, the majority of beaches along Chambers and Jefferson Counties are contained within the McFaddin National Wildlife Refuge (MNWR), Sea Rim State Park (SRSP), and Texas Point National Wildlife Refuge (TPNWR), warranting a management scheme similar to that at PINS and other protected beaches. Nesting has not been documented in the 2 uppermost Texas counties, but these beaches are not currently patrolled for sea turtles aside from a weekly stranding survey conducted by the NOAA STF. Wide beaches appropriate for ridley nesting exist along the eastern portion of MNWR and within SRSP and TPNWR (E. E. Seney pers. obs.), and structured patrols by USFWS and TPWD are necessary to determine whether nesting occurs and to dictate the need for management schemes and increased public education in these areas. Alternatively, funds to monitor potential, as well as known, nesting beaches may be available through competitive conservation grants under Section 6 of the ESA, as administered by TWPD and USFWS.

\section{Concluding remarks}

Use of satellite telemetry has confirmed that beaches and nearshore waters of the upper Texas coast are nesting and internesting habitats for the Kemp's ridley sea turtle. Current management schemes, however, limit researchers' abilities to fully assess sea turtle nesting in the region, and limited protection measures are in force to control and minimize interactions between nesting ridleys and human development, beach use, and in-water activities. Effective protection and management of nesting ridleys requires stakeholder involvement and ultimately coordinated efforts by federal, state, and local agencies. Such a scheme will not only facilitate the recovery of an endangered species, but should minimize liability of involved parties and may facilitate ecotourism.

Acknowledgements. B. Higgins and S. Kethan of the NOAA Fisheries Sea Turtle Facility in Galveston, Texas helped facilitate telemetry conducted by TAMUG. J. Flanagan of the Houston Zoo traveled to Galveston to conduct examinations and ultrasounds. D. Shaver of Padre Island National Seashore answered numerous questions regarding telemetry and nesting. R. Hauch (USACE), M. Ray (TPWD), B. Rhame (TGLO), and C. Yeargan (USFWS) graciously discussed management issues with E.E.S. The inspiration for this paper came from an environmental management course taught at TAMUG by Dr. W. M. von Zharen, and 3 reviewers provided valuable comments for its improvement. Satellite telemetry was funded by the Texas General Land Office Coastal Impact Assistance Program and the TAMUG Department of Marine Biology, and in-kind support was provided by the NOAA Fisheries Service Galveston Laboratory. Research was conducted in accordance with federal, state, and institutional guidelines concerning sampling of endangered species and animal research under USFWS Endangered and Threatened Species Permit TE676379-4, Texas Parks and Wildlife Scientific Permit SPR0390-038, and Texas A\&M University Animal Use Protocol 2005-125.

\section{LITERATURE CITED}

Anonymous (1880) Large sea turtle caught. The Galveston News May 15, 1880, Galveston, TX

Benson SR, Dutton PH, Hitipeuw C, Samber B, Bakarbessy J, Parker D (2007) Post-nesting migrations of leatherback turtles (Dermochelys coriacea) from Jamursba-Medi, Bird's Head Peninsula, Indonesia. Chelonian Conserv Biol 6:150-154

Brader VJM (2005) Shell games: vicarious liability of state and local governments for insufficiently protective regulations under the ESA. Nat Resour J 45:103-133 
Burchfield PM (2005) Texans, turtles, and the early Kemp's ridley population restoration project, 1963-67. Chelonian Conserv Biol 4:835-837

Caillouet CW Jr (2005) Wild and head-started Kemp's ridley nesters, eggs, hatchlings, nesting beaches and adjoining nearshore waters in Texas should receive greater protection. Mar Turtle Newsl 110:1-3

Caillouet CW Jr (2006) Revision of the Kemp's ridley recovery plan. Mar Turtle Newsl 114:2-5

Campbell LM (2003) Contemporary culture, use, and conservation of sea turtles. In: Lutz PL, Musick JA, and Wyneken J (eds) The biology of sea turtles, Vol II. CRC Press, Boca Raton, FL, p 301-338

Carr AF (1963) Panspecific reproductive convergence in Lepidochelys kempi. Ergeb Biol 26:298-303

Coyne MS, Godley BJ (2005) Satellite Tracking and Analysis Tool (STAT): an integrated system for archiving, analyzing and mapping animal tracking data. Mar Ecol Prog Ser 301:1-7

Fontaine C, Shaver D (2005) Head-starting the Kemp's ridley sea turtle, Lepidochelys kempii, at the NMFS Galveston Laboratory, 1978-1992: a review. Chelonian Conserv Biol $4: 838-845$

FWC (2002) Sea turtle conservation guidelines. Florida Fish and Wildlife Conservation Commission, Tallahassee, FL. Available at: www.myfwc.com/seaturtle/Guidelines/ Guidelines.pdf

Gitschlag GR (1996) Migration and diving behavior of Kemp's ridley (Garman) sea turtles along the US southeastern Atlantic coast. J Exp Mar Biol Ecol 205:115-135

> Godley BJ, Broderick AC, Glen F, Hays GC (2003) Post-nesting movements and submergence patterns of loggerhead marine turtles in the Mediterranean assessed by satellite tracking. J Exp Mar Biol Ecol 287:119-134

Godley BJ, Blumenthal JM, Broderick AC, Coyne MS, Godfrey MH, Hawkes LA, Witt MJ (2008) Satellite tracking of sea turtles: Where have we been and where do we go next? Endang Species Res 4:3-22

Hays GC, Luschi P, Papi F, del Seppia C, Marsh R (1999) Changes in behaviour during the inter-nesting period and post-nesting migration for Ascension Island green turtles. Mar Ecol Prog Ser 189:263-273

Hays GC, Åkesson S, Godley BJ, Luschi P, Santidrian P (2001) The implications of location accuracy for the interpretation of satellite-tracking data. Anim Behav 61:1035-1040

Heppell SS, Burchfield PM, Peña LJ (2007) Kemp's ridley recovery: how far have we come, and where are we headed? In: Plotkin PT (ed) Biology and conservation of ridley sea turtles. Johns Hopkins University Press, Baltimore, MD, p 325-335

Hildebrand HH (1963) Hallazgo del área de anidación de la tortuga marina 'lora,' Lepidochelys kempi (Garman), en la costa occidental del Golfo de México. Ciencia 22:105-112

Hooge PN, Eichenlaub WM, Solomon EK (1999) Using GIS to analyze animal movements in the marine environment. US Geological Survey, Glacier Bay Field Station, AK. Available at: www.absc.usgs.gov/glba/gistools/anim_ mov_useme.pdf

IAC Secretariat (2004) Inter-American Convention for the Protection and Conservation of Sea Turtles - an introduction. Pro tempore Secretariat of the Inter-American Convention for the Protection and Conservation of Sea Turtles, San José, Costa Rica

ICC (1991) The business charter for sustainable development: principles for environmental management. International Chamber of Commerce, Paris

IUCN (2006) 2006 IUCN Red List of threatened species. Inter- national Union for the Conservation of Nature and Natural Resources, World Conservation Union, Gland. Available at: www.iucnredlist.org

James MC, Ottensmeyer A, Myers RA (2005) Identification of high-use habitat and threats to leatherback sea turtles in northern waters: new directions for conservation. Ecol Lett 8:195-201

Klima EF, McVey JP (1982) Head-starting the Kemp's ridley turtle, Lepidochelys kempii. In: Bjorndal KA (ed) Biology and conservation of sea turtles. Smithsonian Institution Press, Washington, DC, p 481-487

Lewison RL, Crowder LB, Shaver DJ (2003) The impact of turtle excluder devices and fisheries closures on loggerhead and Kemp's ridley strandings in the western Gulf of Mexico. Conserv Biol 17:1089-1097

LGL Ecological Research Associates (2007) Estimation of shrimp fishing effort in the Gulf of Mexico-2006. Final Annual Effort Report for January-March 2006 to National Marine Fisheries Service, Galveston Laboratory, Galveston, TX

Mansfield KL, Musick JA (2004) Sea turtle diving behavior in Virginia. 2003 Final report submitted to the US Army Corps of Engineers, Norfolk, VA

Márquez-M R, Burchfield PM, Días-F J, Sánchez-P M and others (2005) Status of the Kemp's ridley sea turtle, Lepidochelys kempii. Chelonian Conserv Biol 4:761-766

Mendonça MT, Pritchard PCH (1986) Offshore movements of post-nesting Kemp's ridley sea turtles (Lepidochelys kempi). Herpetologica 42:373-381

Morreale SJ, Standora EA (2005) Western North Atlantic waters: crucial developmental habitat for Kemp's ridley and loggerhead sea turtles. Chelonian Conserv Biol 4:872-882

NOAA (National Oceanic and Atmospheric Administration) (1995) Revised sea turtle/shrimp fishery emergency response plan. US Fed Reg 60:52121-52128

Plotkin PT (1998) Interaction between behavior of marine organisms and the performance of satellite transmitters: a marine turtle case study. Mar Technol Soc J 32:5-10

Pritchard PCH (1997) Evolution, phylogeny, and current status. In: Lutz PL, Musick JA (eds) The biology of sea turtles. CRC Press, Boca Raton, FL, p 1-28

Rebel TP (1974) Sea turtles and the turtle industry of the West Indies, Florida, and the Gulf of Mexico, revised edn. University of Miami Press, Miami, FL

Renaud ML, Williams JA (2005) Kemp's ridley sea turtle movements and migrations. Chelonian Conserv Biol 4:808-816

Renaud ML, Carpenter JA, Williams JA, Landry AMJ (1996) Kemp's ridley sea turtle (Lepidochelys kempii) tracked by satellite telemetry from Louisiana to nesting beach at Rancho Nuevo, Tamaulipas, Mexico. Chelonian Conserv Biol 2:108-109

Rodgers AR, Carr AP, Smith L, Kie JG (2005) HRT: Home Range Tools for ArcGIS. Ontario Ministry of Natural Resources, Centre for Northern Forest Ecosystem Research, Thunder Bay, ON

Rostal DC (2005) Seasonal reproductive biology of the Kemp's ridley sea turtle (Lepidochelys kempii): comparison of captive and wild populations. Chelonian Conserv Biol 4:788-800

Schmid JR, Witzell WN (2006) Seasonal migrations of immature Kemp's ridley turtles (Lepidochelys kempii Garman) along the west coast of Florida. Gulf Mex Sci 2006:28-40

Seaman DE, Powell RA (1996) An evaluation of the accuracy of kernel density estimators for home range analysis. Ecology 77:2075-2085 
Shaver DJ (2005) Analysis of the Kemp's ridley imprinting and headstart project at Padre Island National Seashore, Texas, 1978-88, with subsequent nesting and stranding records on the Texas coast. Chelonian Conserv Biol $4: 846-859$

Shaver DJ, Caillouet CW Jr (1998) More Kemp's ridley turtles return to south Texas to nest. Mar Turtle Newsl 82:1-5

Shaver DJ, Rubio C (2008) Post-nesting movements of wild and headstarted Kemp's ridley sea turtles Lepidochelys kempii in the Gulf of Mexico. Endang Species Res 4:43-55

Shaver DJ, Wibbels T (2007) Head-starting the Kemp's ridley sea turtle. In: Plotkin PT (ed) Biology and conservation of ridley sea turtles. Johns Hopkins University Press, Baltimore, MD, p 297-323

Shaver DJ, Amos AF, Higgins B, Mays J (2005a) Record 42 Kemp's ridley nests found in Texas in 2004. Mar Turtle Newsl 108:1-3

Shaver DJ, Schroeder BA, Byles RA, Burchfield PM, Peña J, Márquez R, Martinez HJ (2005b) Movements and home ranges of adult male Kemp's ridley sea turtles (Lepidochelys kempii) in the Gulf of Mexico investigated by satellite telemetry. Chelonian Conserv Biol 4:817-827

Stoneburner DL (1982) Satellite telemetry of loggerhead sea turtle movement in the Georgia Bight. Copeia 1982: 400-408

Timko RE, Kolz AL (1982) Satellite sea turtle tracking. Mar Fish Rev 44:19-24

TPWD (2006) 2006-2007 Texas commercial fishing guide. Texas Parks and Wildlife Department, Austin, TX

Troëng S, Dutton PH, Evans D (2005a) Migration of hawksbill

Editorial responsibility: Brendan Godley (Editor-in-Chief),

University of Exeter, Cornwall Campus, UK turtles Eretmochelys imbricata from Tortuguero, Costa Rica. Ecography 28:394-402

Troëng S, Evans DR, Harrison E, Lagueux CJ (2005b) Migration of green turtles Chelonia mydas from Tortuguero, Costa Rica. Mar Biol 148:435-447

Turtle Expert Working Group (2000) Assessment update for the Kemp's ridley and loggerhead sea turtle populations in the western north Atlantic. US Department of Commerce, Miami, FL. NOAA Tech Mem NMFS-SEFSC-444

United Nations (1992) Rio Declaration on Environment and Development. International Legal Materials 31:874-880

USFWS \& NMFS (1992) Recovery plan for the Kemp's ridley sea turtle (Lepidochelys kempii). US Fish and Wildlife Service, National Marine Fisheries Service, St. Petersburg, FL

Vielé TG (1858) 'Following the drum': a glimpse of frontier life. Rudd and Carleton, New York

> Vincent C, McConnell BJ, Ridoux V, Fedak MA (2002) Assessment of Argos location accuracy from satellite tags on captive gray seals. Mar Mamm Sci 18:156-166

Whiting S, Hartley S, Lalara S, White D, Bara T, Maminyamunja C, Wurramarrba L (2006) Hawksbill turtle tracking as part of initial sea turtle research and conservation at Groote Eylandt, Northern Australia. Mar Turtle Newsl 114:14-15

Witherington BE, Frazer NB (2003) Social and economic aspects of sea turtle conservation. In: Lutz PL, Musick JA, Wyneken J (eds) The biology of sea turtles, Vol II. CRC Press, Boca Raton, FL, p 355-384

Worton BJ (1995) Using Monte Carlo simulation to evaluate kernel-based home range estimators. J Wildl Manag 59:794-800

Submitted: July 25, 2007; Accepted: November 26, 2007 Proofs received from author(s): December 26, 2007 